\title{
DETERMINATION OF SILICATE ANION CONSTITUTION IN GLASSY AND CRYSTALLINE LEAD SILICATES USING AN IMPROVED TMS TECHNIQUE
}

\author{
D. HOEBBEL ${ }^{1}$, J. GÖTZ $^{2}$, A. VARGHA ${ }^{3}$ and W. WIEKER ${ }^{1}$ \\ 1 Central Institute of Inorganic Chemistry of the Academy of Sciences of the German Democratic \\ Republic, Berlin - Adlershof, GDR \\ 2 Joint Laboratory for Silicate Research of the Czechoslovak Academy of Sciences and the Institute of \\ Chemical Technology, Prague, Czechoslovakia \\ ${ }^{3}$ Research Laboratory for Inorganic Chemistry, Hungarian Academy of Sciences, Budapest, Hungary
}

Received 10 February 1984

Using the DMF trimethylsilylation technique developed by Tamás, Sarkar and Roy, the distribution of silicate anions in lead silicate glasses of the composition range $\mathrm{PbO} \cdot \mathrm{SiO}_{2}-4 \mathrm{PbO}$. $\mathrm{SiO}_{2}$ has been reinvestigated. The obtained results agree with earlier findings except for the tetrameric chain anion $\left[\mathrm{Si}_{4} \mathrm{O}_{13}\right]^{10-}$, which had not been found before. Crystallization of glassy $\mathrm{PbO} \cdot \mathrm{SiO}_{2}$ proceeds via the formation of low-molecular silicate anions $\left[\mathrm{Si}_{2} \mathrm{O}_{7}\right]^{6-},\left[\mathrm{Si}_{4} \mathrm{O}_{13}\right]_{(\mathrm{II})}^{10-}$ and $\left[\mathrm{Si}_{7} \mathrm{O}_{22}\right]^{16-}$, which characterize the low-temperature crystalline polymorph $\mathrm{T}-\mathrm{PbO} \cdot \mathrm{SiO}{ }_{2}$. Further heat treatment turns $\mathrm{T}-\mathrm{PbO} \cdot \mathrm{SiO}_{2}$ into alamosite, characterized by polysilicate chain anions $\left[\mathrm{SiO}_{3}^{2-}\right]_{\infty}$.

\section{Introduction}

Since 1970, significant work has been done to develop chemical techniques for the determination of silicate anions in crystalline and glassy silicates. Most of these methods are based on the trimethylsilylation of silicate anions and the subsequent separation of the formed TMS-derivatives by gas- or thin layer chromatography. Various methods of trimethylsilylation have been reported; their practical value depends on their ability to suppress side reactions, e.g. hydrolytical breakage of $\mathrm{Si}-\mathrm{O}-\mathrm{Si}$ bonds, condensation of silicate groupings before trimethylsilylation is completed, straightening of ring structures or cyclization of linear silicates during the TMS procedure [1]. The results of several works published recently [2-5] indicate that the DMF trimethylsilylation technique described by Tamás et al. [6] minimizes side reactions. It was found [2,7] to preserve the linear chain $\left[\mathrm{Si}_{4} \mathrm{O}_{13}\right]^{10-}$ present in $\mathrm{Ag}_{10} \mathrm{Si}_{10} \mathrm{O}_{13}$, which under conditions of direct trimethylsilylation [8] tends to form a tetrameric ring $\left[\mathrm{Si}_{4} \mathrm{O}_{12}\right]^{8-}$. This induced us to utilize the DMF silylation technique in the present work designed to investigate constitutional changes occurring in silicate anions during the crystallization of glassy $\mathrm{PbO} \cdot \mathrm{SiO}_{2}$. In connection with this, it was desirable to compare the results of the DMF 
trimethylsilylation technique with those of the direct trimethylsilylation technique used in our preceding works. For this purpose, the DMF technique was also applied to reinvestigate the constitution of silicate anions present in glasses of the system $\mathrm{PbO}-\mathrm{SiO}_{2}$, which had been studied previously [9].

\section{Experimental}

The binary lead silicate glasses covering the composition range $\mathrm{PbO}$. $\mathrm{SiO}_{2}-4 \mathrm{PbO} \cdot \mathrm{SiO}_{2}$ were identical with those studied in ref. [9] where all the preparation details were described. For trimethylsilylation, about $20 \mathrm{mg}$ of finely ground glass was added to a continuously stirred mixture of $5 \mathrm{ml}$ hexamethyldisiloxane, $10 \mathrm{ml}$ dimethylformamide and $5 \mathrm{ml}$ trimethylchloro-

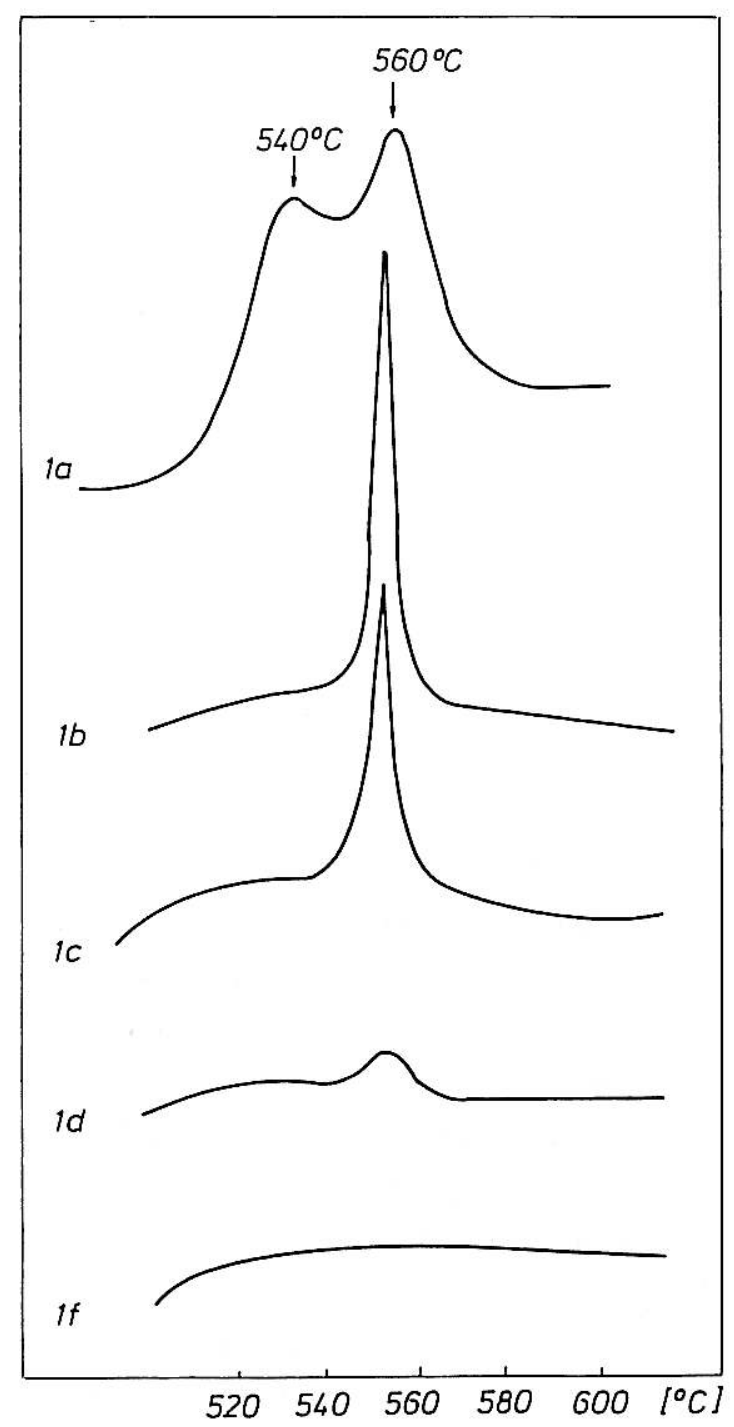

Fig. 1. DTA measurements ov various samples of $\mathrm{PbO} \cdot \mathrm{SiO}_{2}$. Curves: 1a, original glass without heat treatment, $1 \mathrm{~b}$, sample heated $2 \mathrm{~h}$ at $550^{\circ} \mathrm{C}, 1 \mathrm{c}$, sample heated $6 \mathrm{~h}$ at $550^{\circ} \mathrm{C}, 1 \mathrm{~d}$, sample heated $8 \mathrm{~h}$ at $550^{\circ} \mathrm{C}, 1 \mathrm{f}$, sample heated $12 \mathrm{~h}$ at $550^{\circ} \mathrm{C}$. 
silane, which had been kept for $15 \mathrm{~min}$ at $20^{\circ} \mathrm{C}$. The suspension was stirred for $30 \mathrm{~min}$ and then a solution of tetradecan/heptan was added to serve as internal standard for gas chromatographic analysis. After hydrolysis at $+5^{\circ} \mathrm{C}$, the upper organic phase was separated, washed five times with $40 \mathrm{ml} \mathrm{H}_{2} \mathrm{O}$ and then directly injected into the gas chromatograph. A Hewlett - Packard model 5830 A device equipped with a flame - ionization detector and capillary inlet system model $18740 \mathrm{~A}$ was used. The column (length $20 \mathrm{~m}$, diameter $0.25 \mathrm{~mm}$ ) was of Pyrex glass covered with OV-1 as a stationary phase. It should be stressed that the Amberlyst treatment of the silylation products was omitted, as according to refs. $[10,11]$ it catalyzes side reactions. For the identification of the separated TMS species, previously prepared standards and mass spectrometric measurements were used. The quantitative determination of TMS esters was carried out as described in ref. [4].

For the crystallization study of glassy $\mathrm{PbO} \cdot \mathrm{SiO}_{2}$, its crystallization interval was found by DTA measurements: about $0.66 \mathrm{~g}$ of finely powdered glass (grain size $<40 \mu \mathrm{m}$ ) was heated in the Pt crucible of a Netzsch STA thermoanalyzer (model 429) using the highest available sensitivity $0.05 \mathrm{mV}$. Between $20-300^{\circ} \mathrm{C}$, the glass was heated at $5^{\circ} \mathrm{C} \mathrm{min}-1$, from $300^{\circ} \mathrm{C}$ upwards the heating rate was lowered to $2^{\circ} \mathrm{C} . \mathrm{min}^{-1}$ to avoid the overlapping of neighboring peaks, As shown in the DTA recording (fig. 1a), crystallization is indicated by the appearance of a doubly-peaked exotherm, its first maximum at $540^{\circ} \mathrm{C}$ followed by a second peak at $560^{\circ} \mathrm{C}$. This suggested that the most convenient temperature for an isothermal crystallization study would be $550^{\circ} \mathrm{C}$.

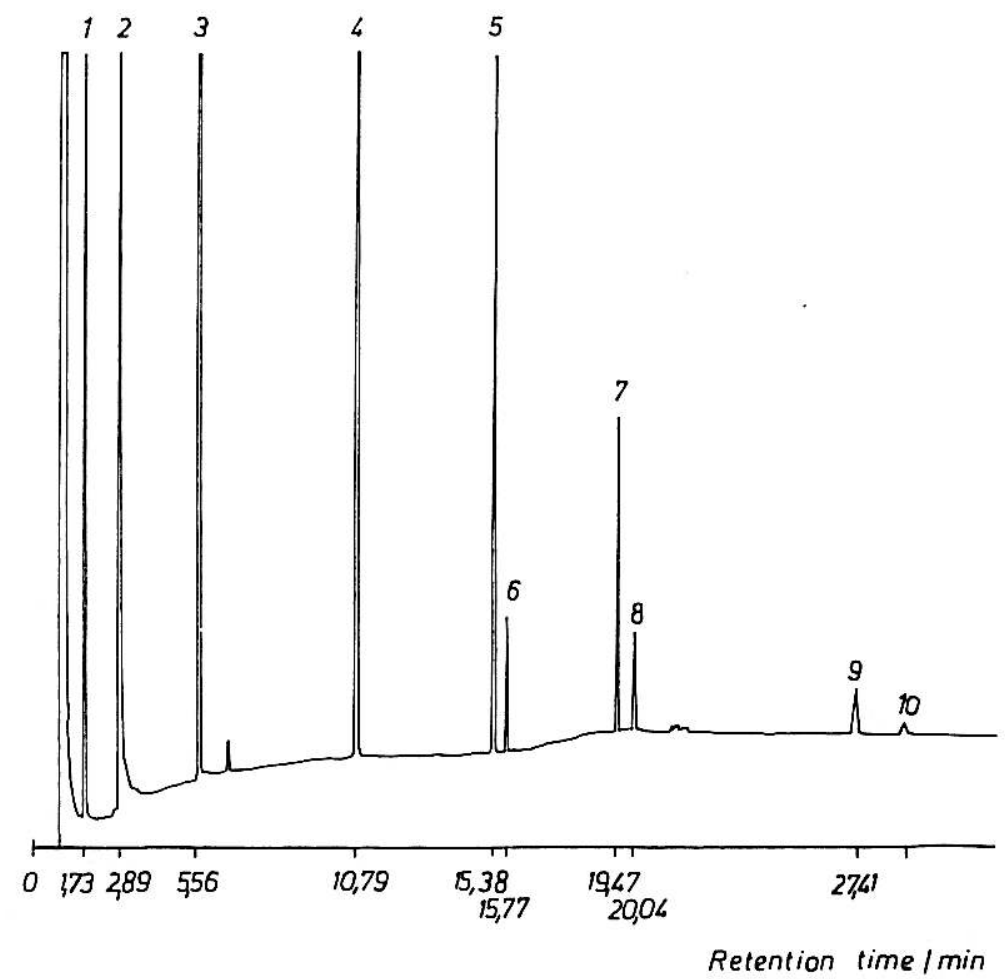

Fig. 2. Chromatogram of TMS derivatives obtained from glassy $3 \mathrm{PbO} \cdot \mathrm{SiO}_{2}$. 
Orientational experimental confirmed this idea. Therefore, samples of finely ground $\mathrm{PbO} \cdot \mathrm{SiO}_{2}$ glass (grain size $<40 \mu \mathrm{m}$ ) were heated for various times at $550^{\circ} \mathrm{C}$, cooled in air and again ground to grain size $<40 \mu \mathrm{m}$. These samples were studied by DTA and X-ray diffraction; their silicate anions were investigated utilizing the TMS procedure described above. In addition to this, the molybdate method [12] was used to obtain more information on high molecular silicate species present in the samples studied.

\section{Results and discussion}

Fig. 2 represents a typical chromatogram of TMS derivatives obtained by trimethylsilylation of glassy $3 \mathrm{PbO} \cdot \mathrm{SiO}_{2}$. Peaks $1,3,4$ and 5 correspond to TMS derivatives of $\left[\mathrm{SiO}_{4}\right]^{4-}$ and of the linear anions $\left[\mathrm{Si}_{2} \mathrm{O}_{7}\right]^{6-},\left[\mathrm{Si}_{3} \mathrm{O}_{10}\right]^{8-}$ and $\left[\mathrm{Si}_{4} \mathrm{O}_{13}\right]_{(\mathrm{I})}^{10-}$, respectively. Peak 6 is due to the trimethylsilylated ester of the branched tetrameric isomer $\left[\mathrm{Si}_{4} \mathrm{O}_{13}\right]_{(I 1)}^{10-}$ with the constitution

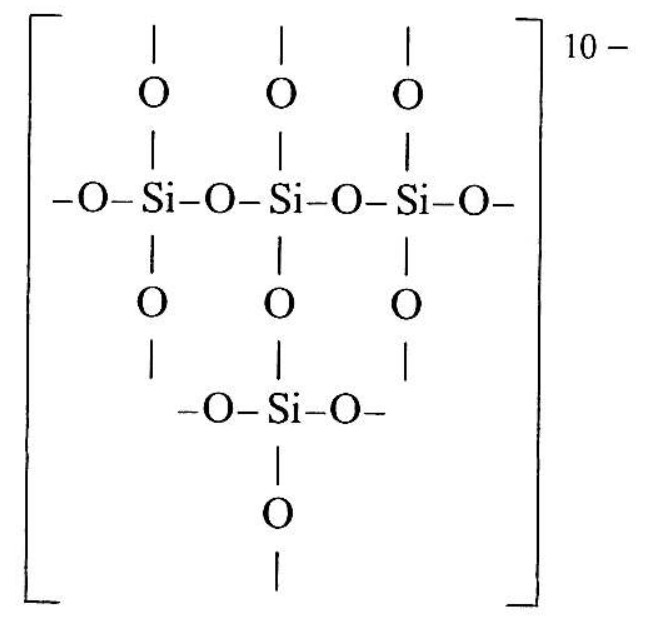

Retention times of peaks 7 and 9 suggest that according to the homology rule they are caused by TMS derivatives of pentameric and hexameric chain-like anions $\left[\mathrm{Si}_{5} \mathrm{O}_{16}\right]_{(1)}^{12-}$ and $\left[\mathrm{Si}_{6} \mathrm{O}_{19}\right]_{(1)}^{14-}$ respectively. Peaks 8 and 10 possibly indicate the presence of isomeric branched TMS esters of $\left[\mathrm{Si}_{5} \mathrm{O}_{16}\right]_{(I I)}^{12-}$ and $\left[\mathrm{Si}_{6} \mathrm{O}_{19}\right]_{(\mathrm{II})}^{14-}$.

Quantitative evaluation of chromatograms obtained by trimethylsilylation of glasses in the range $\mathrm{PbO} \cdot \mathrm{SiO}_{2}-4 \mathrm{PbO} \cdot \mathrm{SiO}_{2}$ leads to the data given in table 1. From there it is evident that this new investigation confirms the main result of the previous study [9], namely that binary lead silicate glasses of the studied composition are characterized by a polyanionic silicate distribution created by various structurally different silicate anions. In the lead-rich composition $4 \mathrm{PbO} \cdot \mathrm{SiO}_{2}$ and $3 \mathrm{PbO} \cdot \mathrm{SiO}_{2}$, more than $90 \mathrm{wt} \%$ of total silica is formed by monomeric $\left[\mathrm{SiO}_{4}\right]^{4-}$ and the linear anions $\left[\mathrm{Si}_{2} \mathrm{O}_{7}\right]^{6-},\left[\mathrm{Si}_{3} \mathrm{O}_{10}\right]^{8-}$ and $\left[\mathrm{Si}_{4} \mathrm{O}_{13}\right]_{(\mathrm{I})}^{10-}$. The amount of silicate anions with probably pentameric and hexameric linear or branched chain structures in these glasses is very low. 
Table 1

Results of silicate anion analysis of $\mathrm{PbO}-\mathrm{SiO}_{2}$ glasses (wt\% $\mathrm{Si}$ of total amount of $\mathrm{Si}$ in glasses)

\begin{tabular}{|c|c|c|c|c|c|}
\hline \multirow[t]{2}{*}{ Silicate anion } & \multicolumn{5}{|c|}{ Molar ratio $\mathrm{PbO}: \mathrm{SiO}_{2}$} \\
\hline & 4.14 & 3.08 & 2.01 & 1.50 & 1.00 \\
\hline$\left[\mathrm{SiO}_{4}\right]^{4-}$ & 57 & 38 & 19 & 9 & - \\
\hline$\left[\mathrm{Si}_{2} \mathrm{O}_{7}\right]^{6-}$ & 26 & 29 & 14 & 7 & - \\
\hline$\left[\mathrm{Si}_{3} \mathrm{O}_{10}\right]^{8-}$ & 11 & 19 & 11 & 7 & - \\
\hline$\left[\mathrm{Si}_{4} \mathrm{O}_{13}\right]_{(\mathrm{I})}^{10-}$ & 4 & 8 & 10 & 4 & - \\
\hline$\left[\mathrm{Si}_{4} \mathrm{O}_{13}\right]_{(11)}^{\mathrm{i0}-}$ & 1 & 1 & 1 & 1 & - \\
\hline$\left[\mathrm{Si}_{5} \mathrm{O}_{16}\right]_{(\mathrm{I})}^{12-}$ & 1 & 3 & 5 & 3 & - \\
\hline$\left[\mathrm{Si}_{5} \mathrm{O}_{16}\right]_{(11)}^{12-}$ & - & 1 & 2 & 1 & - \\
\hline Unknown & - & 1 & 3 & 2 & 1 \\
\hline $\begin{array}{l}\text { Higher molecular } \\
\text { silicates }\end{array}$ & - & - & 35 & 66 & 99 \\
\hline
\end{tabular}

In glassy $4 \mathrm{PbO} \cdot \mathrm{SiO}_{2}$ and $3 \mathrm{PbO} \cdot \mathrm{SiO}_{2}$, it is possible to determine almost $100 \mathrm{wt} \%$ of the present silica as TMS derivatives. Compositions with higher percentages of $\mathrm{SiO}_{2}$ are characterized by decreased solubility in mineral acids and an increased amount of higher molecular silicate anions, the TMS derivatives of which cannot be detected by present gas chromatographic methods. Consequently, in glassy $2 \mathrm{PbO} \cdot \mathrm{SiO}_{2}, 3 \mathrm{PbO} \cdot 2 \mathrm{SiO}_{2}$ and $\mathrm{PbO} \cdot \mathrm{SiO}_{2}$ only 65 wt $\%, 34 \mathrm{wt} \%$ and $1 \mathrm{wt} \%$ of weighed in $\mathrm{SiO}_{2}$ respectively, are detected by TMS analysis. The percentage of higher molecular silicate groupings listed in table 1 was calculated as the difference between the weighed in $\mathrm{SiO}_{2}$ and the total silica found by quantitative evaluation of gas chromatography of TMS derivatives. Results obtained in a previous study by a combination of TMs analysis, paper chromatography and the molybdate method indicate that within this category of more condensed species a distribution of various medium - and higher molecular silicate anions exists [9].

Comparison of the obtained percentages of mono-, dimeric and trimeric silicate anions as well as of high molecular silicate groupings shows a satisfactory agreement between the present work and the results published several years ago [9]. However, there is a substantial difference in the constitution of the detected tetrameric silicate species: whereas in ref. [9] the existence of cyclic anions $\left[\mathrm{Si}_{4} \mathrm{O}_{12}\right]^{8-}$ was reported, the present investigation finds only chain-like anions $\left[\mathrm{Si}_{4} \mathrm{O}_{13}\right]_{(\mathrm{I})}^{10-}$ and small amounts of its branched isomer $\left[\mathrm{Si}_{4} \mathrm{O}_{13}\right]_{(\mathrm{II})}^{10-}$. This discrepancy is explained by the finding $[2,7]$ that the linear unit $\left[\mathrm{Si}_{4} \mathrm{O}_{13}\right]_{(\mathrm{I})}^{10-}$ tends to form cyclic $\left[\mathrm{Si}_{4} \mathrm{O}_{12}\right]^{8-}$ in acid solution during the trimethylsilylation procedure described in ref. [8]. In this connection it was of interest to apply the DMF silylation technique to reinvestigate the constitution of silicate anions in crystalline $\mathrm{M}-2 \mathrm{PbO} \cdot \mathrm{SiO}_{2}$, which had been found to contain tetrameric rings $\left[\mathrm{Si}_{4} \mathrm{O}_{12}\right]^{8-}$ by both direct trimethylsilylation [13] and crystal structure analysis [14]. Our new results confirm the prevailance of tetrameric anions $\left[\mathrm{Si}_{4} \mathrm{O}_{12}\right]^{8-}$ in the medium-temperature modification of crys- 
talline $2 \mathrm{PbO} \cdot \mathrm{SiO}_{2}$, which consequently should be written as $\left[\mathrm{Pb}_{2} \mathrm{O}\right]_{4} \cdot\left[\mathrm{Si}_{4} \mathrm{O}_{12}\right]$.

DTA measurements on glassy $\mathrm{PbO} \cdot \mathrm{SiO}_{2}$ indicate, that it crystallizes in two main steps (fig. 1a). First, a low temperature crystalline polymorph is formed [DTA peak $540^{\circ} \mathrm{C}$ ), which by further heating turns into a high-temperature modification (DTA peak $560^{\circ} \mathrm{C}$ ). Isothermal heating of glassy $\mathrm{PbO} \cdot \mathrm{SiO}_{2}$ leads to he low-temperature crystalline derivative, if heat-treatment is short (fig. 1b). Samples kept at $550^{\circ} \mathrm{C}$ for $12 \mathrm{~h}$ (fig. 1f) or longer show no DTA peak, being fully transformed into the high temperature polymorph.

$\mathrm{X}$-ray difractograms of the original glass and all crystalline derivatives are depicted in fig. 3. In the sample kept $2 \mathrm{~h}$ at $550^{\circ} \mathrm{C}$ the three most prominent diffraction peaks are at $d=3.23 \AA, 2.864 \AA$ and $1.875 \AA$; these diffraction lines also characterize the specimen heat-treated $4 \mathrm{~h}$ at $550^{\circ} \mathrm{C}$. Detailed comparison of all peaks with published data shows that the diffraction peaks of both samples are identical with those of $\mathrm{T}-\mathrm{PbO} \cdot \mathrm{SiO}_{2}$ described by Billhardt [15]

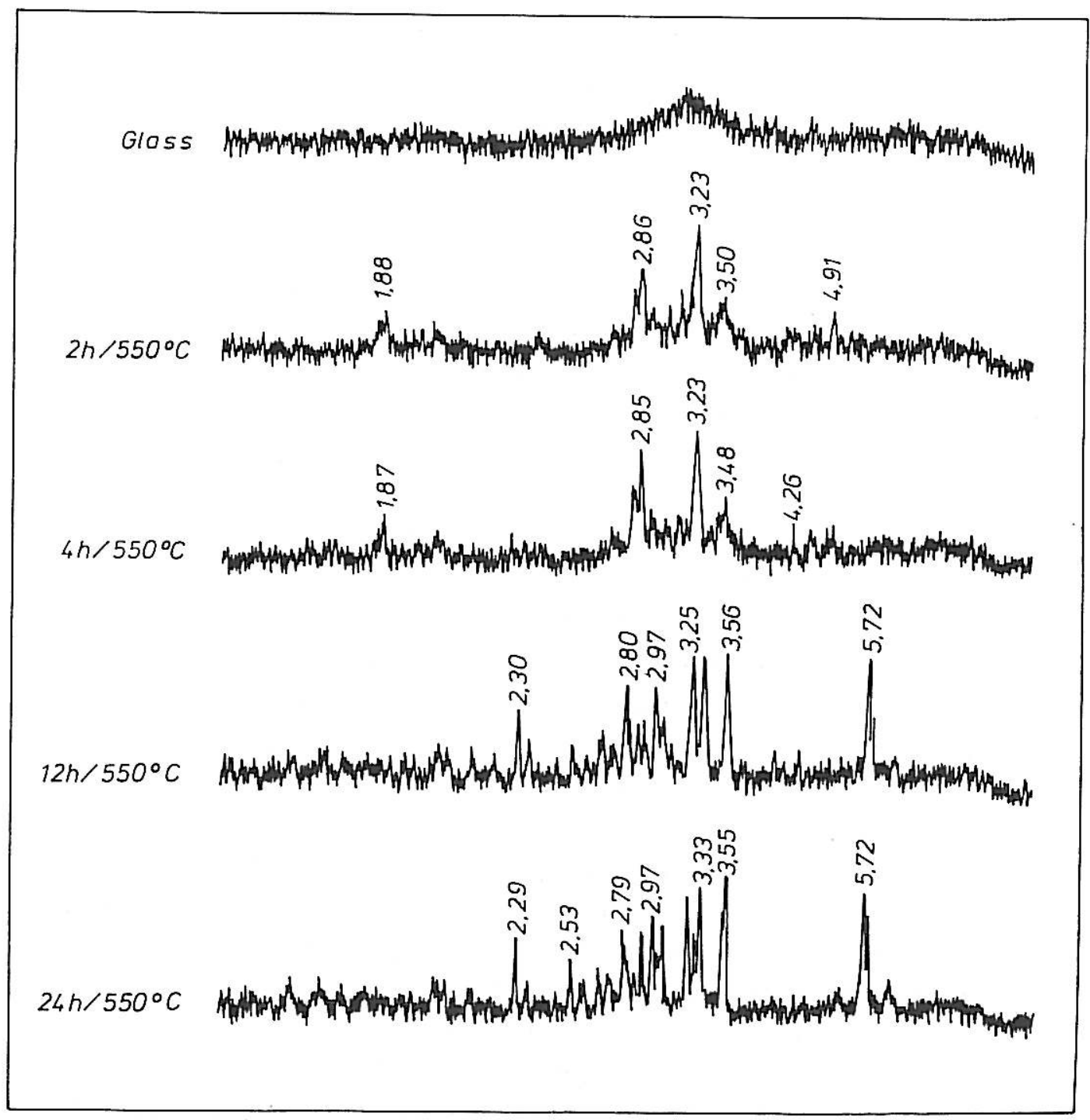

Fig. 3. XRD recordings of glassy $\mathrm{PbO} \cdot \mathrm{SiO}_{2}$ and its crystalline derivatives prepared by heating at $550^{\circ} \mathrm{C}$ from 2 to $24 \mathrm{~h}$. 
$12]$.

and of hexagonal $\mathrm{PbO} \cdot \mathrm{SiO}_{2}$ measured by Smart and Glasser [16]. Further heating at $550^{\circ} \mathrm{C}$ leads finally to the high-temperature derivative fully developed after $24 \mathrm{~h}$. Its XRD characteristics are identical with those of $\mathrm{H}-\mathrm{PbO} \cdot \mathrm{SiO}_{2}$ (alamosite) published in ref. [15]. Schematically, the devitrification of glassy $\mathrm{PbO} \cdot \mathrm{SiO}_{2}$ can be depicted as follows:

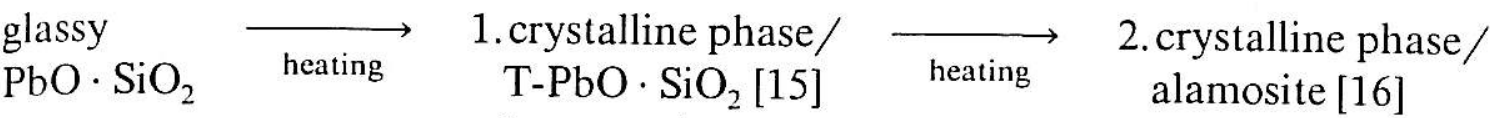

$$
\begin{aligned}
& \text { hexagonal } \\
& \mathrm{PbO} \cdot \mathrm{SiO}_{2}[16] \\
& \text { high-temperature } \\
& \mathrm{PbO} \cdot \mathrm{SiO}_{2} \text { [15] }
\end{aligned}
$$

The existence of another metastable polymorph "low $\mathrm{PbO} \cdot \mathrm{SiO}_{2}$ " [16] has not been observed, probably due to the higher temperature of isothermal crystallization.

Fig. 4 depicts the molybdate reaction curves of various heat-treated $\mathrm{PbO}$. $\mathrm{SiO}_{2}$ samples. It shows that with longer heating times the curves approach that of a chain - forming polysilicate: the molybdate curve of crystalline $\mathrm{PbO} \cdot \mathrm{SiO}_{2}$ kept $24 \mathrm{~h}$ at $710^{\circ} \mathrm{C}$ is very close to the curve of polysilicate $\left[\mathrm{Li}_{2} \mathrm{SiO}_{3}\right]_{\infty}$ used as standard. These findings are in full agreement with the above given XRD results and confirm that the crystalline high - temperature modification of $\mathrm{PbO} \cdot \mathrm{SiO}_{2}$ is formed prevailingly by polysilicate anions $\left[\mathrm{SiO}_{3}{ }^{2-}\right]_{\infty}$. A semi-

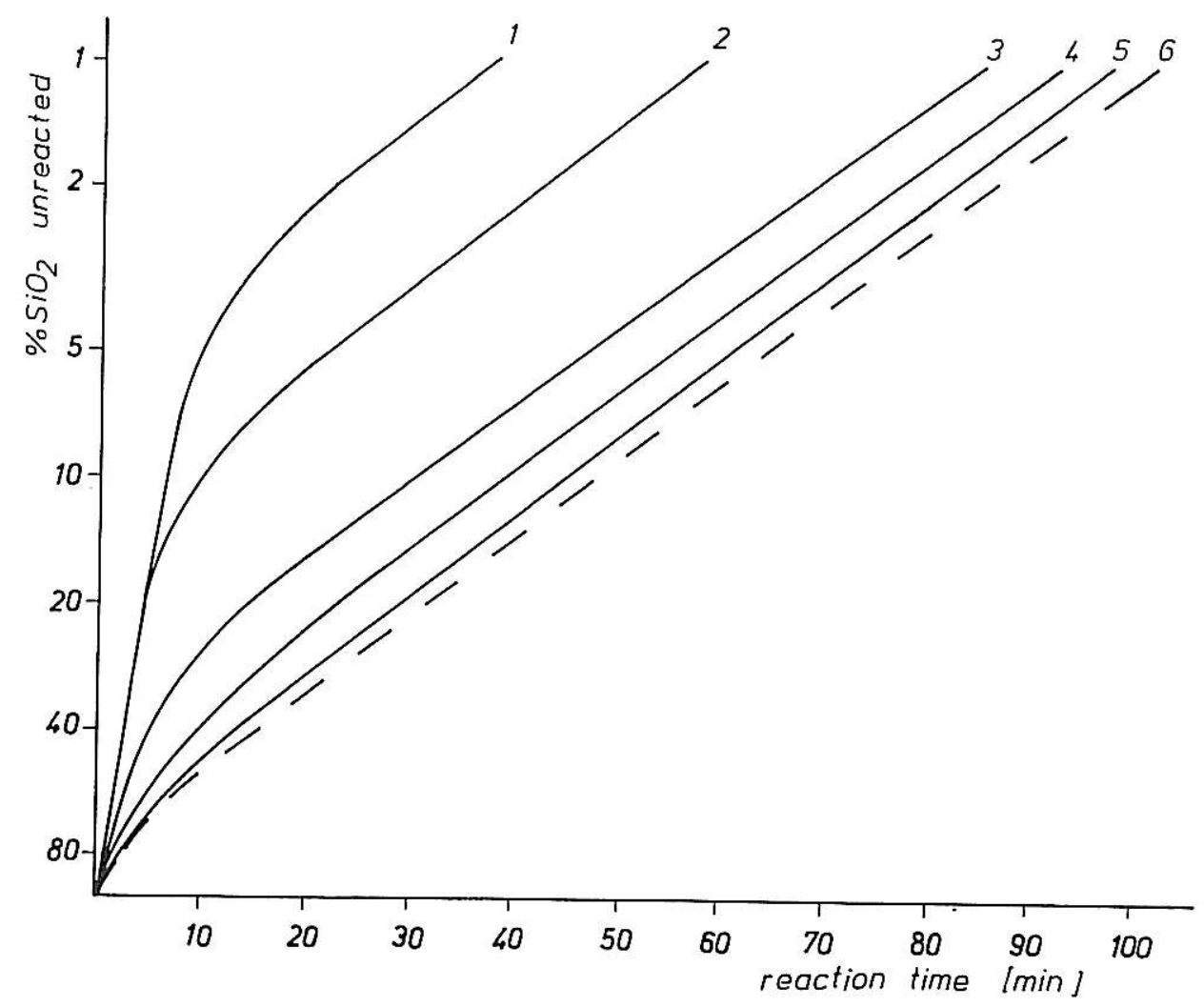

Fig. 4. Molybdate reaction curves of various heat - treated samples of $\mathrm{PbO} \cdot \mathrm{SiO}_{2}$. Curves: $1,0.5 \mathrm{~h}$ at $550^{\circ} \mathrm{C}, 2,4 \mathrm{~h}$ at $550^{\circ} \mathrm{C}, 3,6 \mathrm{~h}$ at $550^{\circ} \mathrm{C}, 4,24 \mathrm{~h}$ at $550^{\circ} \mathrm{C}, 5,24 \mathrm{~h}$ at $710^{\circ} \mathrm{C}, 6$, standard curve of $\left[\mathrm{Li}_{2} \mathrm{SiO}_{3}\right]_{\infty}$. The percentage of polysilicate anions derived from the above given curves is listed in table 2. 
Table 2

Silicate anions determined in glassy and crystalline $\mathrm{PbO} \cdot \mathrm{SiO}_{2}(\mathrm{wt} \% \mathrm{Si}$ of total amount of $\mathrm{Si}$ in solid samples)

\begin{tabular}{|c|c|c|c|c|c|c|}
\hline \multirow[t]{2}{*}{ Sample } & \multicolumn{4}{|c|}{ TMS method [7] } & \multicolumn{2}{|c|}{ Molybdate method [9] } \\
\hline & {$\left[\mathrm{Si}_{2} \mathrm{O}_{7}\right]^{6-}$} & {$\left[\mathrm{Si}_{4} \mathrm{O}_{13}\right]_{(\mathrm{II})}^{10-}$} & {$\left[\mathrm{Si}_{7} \mathrm{O}_{22}\right]^{16-}$} & $\begin{array}{l}\text { Poly- } \\
\text { meric } \\
\text { silicate } \\
\text { anions } \\
\text { not } \\
\text { analy- } \\
\text { zable by } \\
\text { TMS } \\
\text { method } \\
\end{array}$ & $\begin{array}{l}\text { Poly- } \\
\text { silicate } \\
\text { anions } \\
{\left[\mathrm{SiO}_{3}^{2-}\right]_{\infty}}\end{array}$ & $\begin{array}{l}\text { Poly- } \\
\text { meric } \\
\text { silicates } \\
\text { undetec- } \\
\text { table by } \\
\text { molybdate } \\
\text { method }\end{array}$ \\
\hline $\begin{array}{l}\text { Unheated } \\
\mathrm{PbO} \cdot \mathrm{SiO}_{2} \\
\text { glass }\end{array}$ & 0 & 0 & 0 & 99 & 0 & 84 \\
\hline $\begin{array}{l}\text { Heated } \\
\qquad 0.5 \mathrm{~h} / 550^{\circ} \mathrm{C}\end{array}$ & 3 & 14 & 23 & 60 & 4 & 43 \\
\hline $\begin{array}{l}\text { Heated } \\
2 \mathrm{~h} / 550^{\circ} \mathrm{C}\end{array}$ & 2 & 10 & 14 & 73 & 9 & 42 \\
\hline $\begin{array}{l}\text { Heated } \\
6 \mathrm{~h} / 550^{\circ} \mathrm{C}\end{array}$ & 2 & 8 & 12 & 78 & 24 & 33 \\
\hline $\begin{array}{l}\text { Heated } \\
\qquad 24 \mathrm{~h} / 550^{\circ} \mathrm{C}\end{array}$ & 2 & 1 & 1 & 95 & 53 & 20 \\
\hline $\begin{array}{l}\text { Heated } \\
\qquad 24 \mathrm{~h} / 710^{\circ} \mathrm{C}\end{array}$ & 2 & 0 & 0 & 95 & 66 & 7 \\
\hline
\end{tabular}

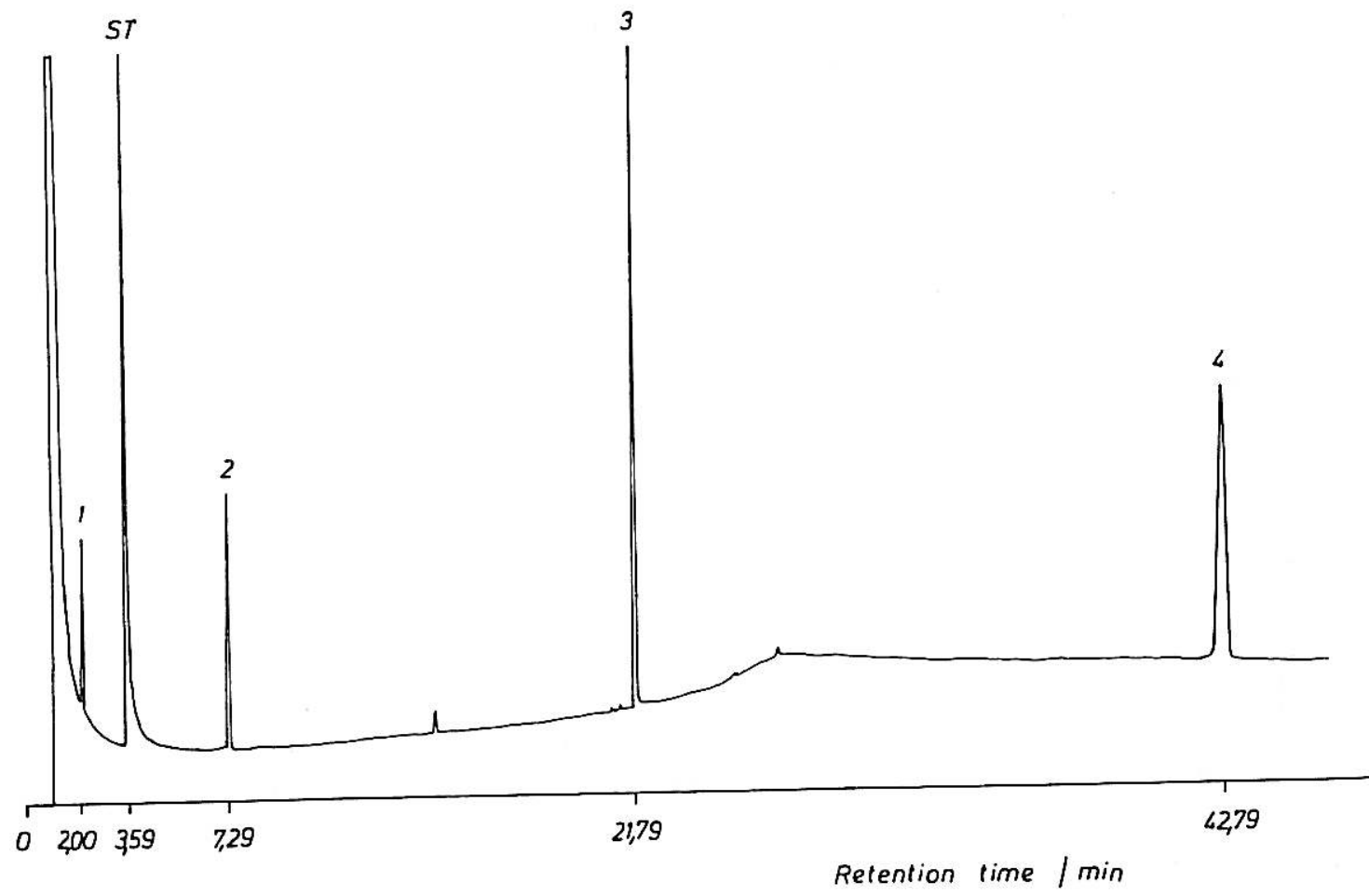

Fig. 5. GLC recording of TMS esters obtained from $\mathrm{PbO} \cdot \mathrm{SiO}_{2}$ heated $2 \mathrm{~h}$ at $550^{\circ} \mathrm{C}$. ST $=$ peak of internal standard 1, TMS derivative of $\left[\mathrm{SiO}_{4}\right]^{4-}, 2$, TMS derivative of $\left[\mathrm{Si}_{2} \mathrm{O}_{7}\right]^{6-}, 3, \mathrm{TMS}$ derivative of $\left[\mathrm{Si}_{4} \mathrm{O}_{13}\right]_{(\mathrm{II})}^{10-}, 4$, TMs derivative of unknown anion. 


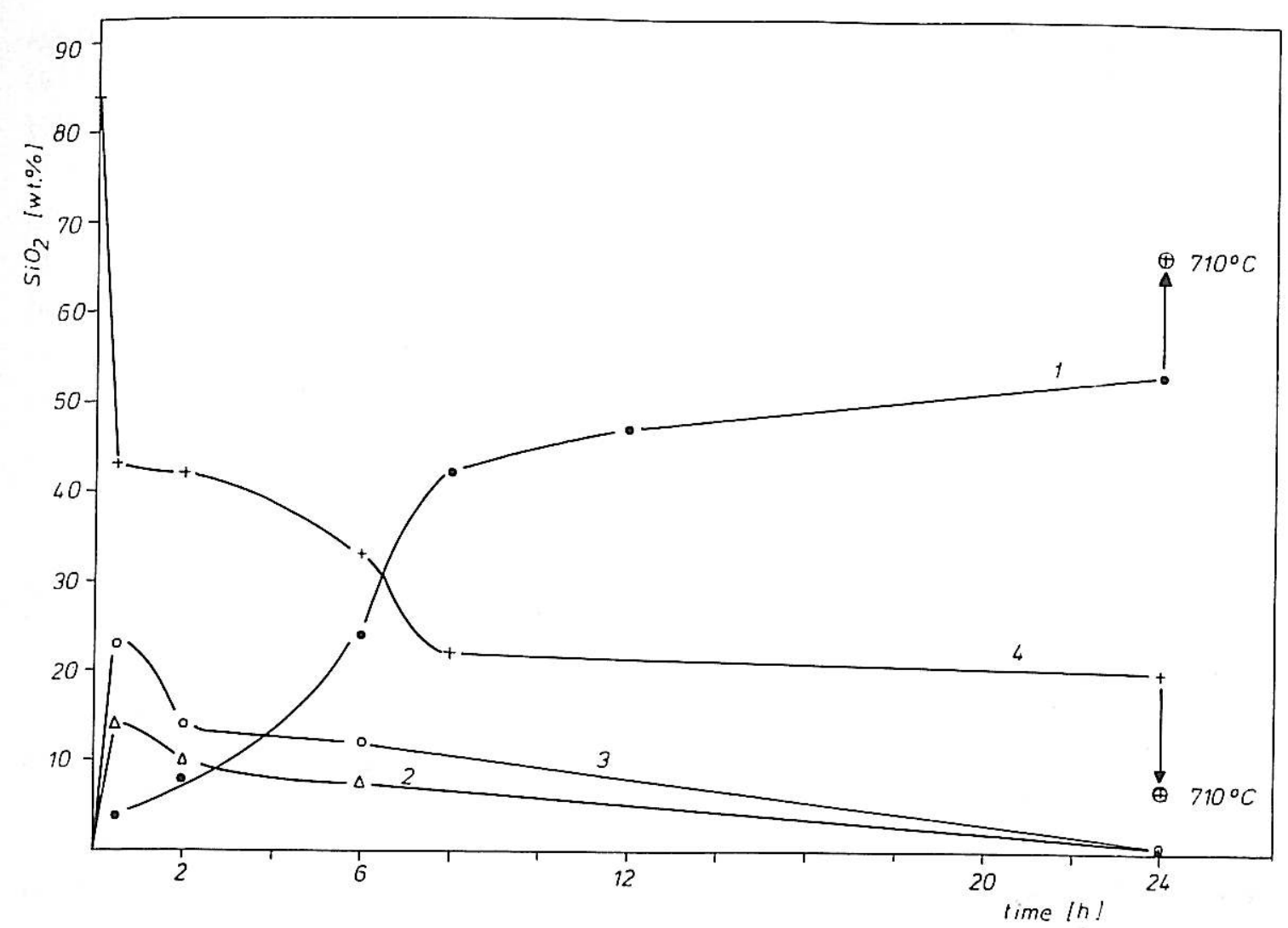

Fig. 6. Changes in silicate anion types caused by calcination of glassy $\mathrm{PbO} \cdot \mathrm{SiO}_{2}$ at $550^{\circ} \mathrm{C}$ for times varying from $0.5-24 \mathrm{~h}$.

quantitative evaluation of these molybdate curves based on the assumption that their final linear ascent is due to polysilicates leads to the data listed in table 2 in the column "polysilicate anions".

Fig. 5 represents the gas chromatogram obtained from a sample heated $2 \mathrm{~h}$ at $550^{\circ} \mathrm{C}$. The diagram contains four main peaks, of which the peaks corresponding to TMS derivatives of $\left[\mathrm{Si}_{2} \mathrm{O}_{7}\right]^{6-},\left[\mathrm{Si}_{4} \mathrm{O}_{13}\right]_{(I 1)}^{10-}$ and of an unknown silicate anion (peak 4) are most prominent. Mass spectrometry of the TMS ester causing peak 4 yields a molecular weight of 1644; retention data indicate that this compound contains more than 14 trimethylsilyl groups $\left(\mathrm{CH}_{3}\right)_{3}-\mathrm{Si}-\mathrm{O}_{0.5}$. Evaluation of these parameters leads to the assumption that peak 4 is due to a trimethylsilylated heptameric silicate chain with one $\mathrm{Si}-\mathrm{OH}$ group present. From this it may be concluded that the unknown silicate anion is a chain-forming heptasilicate corresponding to the formula $\left[\mathrm{Si}_{7} \mathrm{O}_{22}\right]^{16-*}$. By quantitative evaluation of gas chromatographic measurements, the data listed in table 2 were obtained.

Glassy $\mathrm{PbO} \cdot \mathrm{SiO}_{2}$ as well as the second crystalline modification cannot be analyzed by the TMS technique, because TMS derivatives of higher polymer-

* In this connection it should be added that the anion $\left[\mathrm{Si}_{3} \mathrm{O}_{10}\right]^{8-}$ reported in ref. [17] could not be found in this investigation. 
ized silicate anions are not separable by the presently available gas chromatography. Crystalline samples formed from glassy $\mathrm{PbO} \cdot \mathrm{SiO}_{2}$ by heating at $550^{\circ} \mathrm{C}$ from $30 \mathrm{~min}$ to $120 \mathrm{~min}$ contain considerable percentages of low molecular silicates, mainly $\left[\mathrm{Si}_{7} \mathrm{O}_{22}\right]^{16-}$ and $\left[\mathrm{Si}_{4} \mathrm{O}_{13}\right]_{(\mathrm{II})}^{10-}$.

Fig. 6 combines the results of both the molybdate method and the TMS technique. Curve 1 illustrates the increase in the percentage of polysilicate anions $\left[\mathrm{SiO}_{3}{ }^{2-}\right]_{\infty}$, curves 2 and 3 indicate the time-limited appearance of low-molecular silicates $\left[\mathrm{Si}_{4} \mathrm{O}_{13}\right]_{(\mathrm{II})}^{10-}$ and $\left[\mathrm{Si}_{7} \mathrm{O}_{22}\right]^{16-}$ respectively. Curve 4 expresses the percentage of molybdate inactive silica; it represents high molecular silicate species originally present in the glass which are not analyzable either by molybdate or by TMS techniques.

From fig. 6, the following general picture of the gradual changes in the constitution of silicate anions occuring during the transition from glassy $\mathrm{PbO} \cdot \mathrm{SiO}_{2}$ to the high temperature modification of crystalline $\mathrm{PbO} \cdot \mathrm{SiO}_{2}$ is obtained: glassy $\mathrm{PbO} \cdot \mathrm{SiO}_{2}$ contains mutually interlinked high molecular silicate anions very resistive to structural rearrangement; this explains the relatively high glassiness of this composition. If energy is applied by exposing the glassy material to temperatures sufficiently above $T_{\mathrm{g}}$ (the value of $T_{\mathrm{g}}$ for glassy $\mathrm{PbO} \cdot \mathrm{SiO}_{2}$ measured by DTA is $395^{\circ} \mathrm{C}$ ), the mobility of the various structural units increases and this starts a rearrangement process, during which $\mathrm{Si}-\mathrm{O}-\mathrm{Si}$ bonds are severed. In this way, new lower molecular silicates anions appear, which are more easily arranged into a crystalline structure. The low-temperature crystalline polymorph originating from glassy $\mathrm{PbO} \cdot \mathrm{SiO}_{2}$ contains about $40 \mathrm{wt} \%$ of $\mathrm{SiO}_{2}$ as high molecular silicates, but also about the same percentage of low molecular anions $\left[\mathrm{Si}_{2} \mathrm{O}_{7}\right]^{6-},\left[\mathrm{Si}_{4} \mathrm{O}_{13}\right]_{(\mathrm{II})}^{10-}$ and $\left[\mathrm{Si}_{7} \mathrm{O}_{22}\right]^{16-}$.

As the branched chain structure of

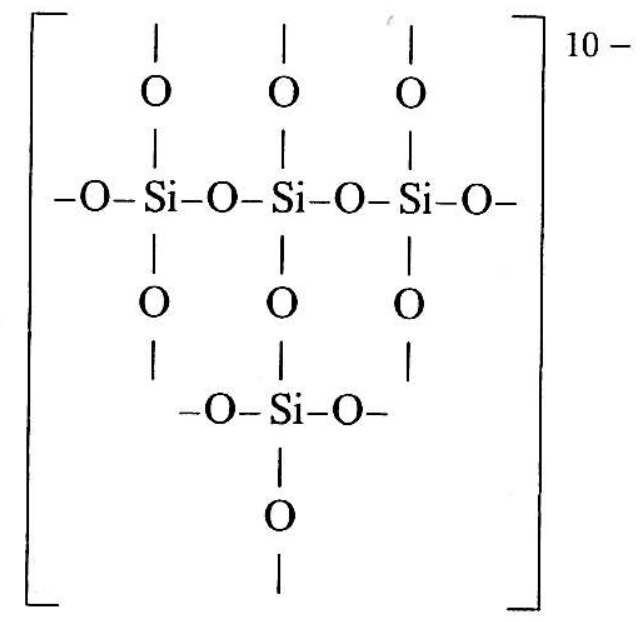

is not a convenient building unit to create polysilicate chains, it may be assumed that this silicate anion is a depolymerization product derived from the original glass. As for the anion $\left[\mathrm{Si}_{7} \mathrm{O}_{22}\right]^{16-}$, at present it is difficult to determine whether it arises by depolymerization or by a chain-forming process in which anions $\left[\mathrm{SiO}_{4}\right]^{4-}$ and $\left[\mathrm{Si}_{2} \mathrm{O}_{7}\right]^{6-}$ participate. If heat treatment is 
sufficiently long, the percentage of high-molecular silicates stemming from the original glass keeps decreasing, these structures being broken into intermediate low-molecular species, which instantly join together and form a polysilicate chain. This explains the gradual disappearance of low-molecular silicate anions $\left[\mathrm{Si}_{2} \mathrm{O}_{7}\right]^{6-},\left[\mathrm{Si}_{4} \mathrm{O}_{13}\right]_{(\mathrm{II})}^{10-}$ and $\left[\mathrm{Si}_{7} \mathrm{O}_{22}\right]^{16-}$ in samples heated more than $6 \mathrm{~h}$ at $550^{\circ} \mathrm{C}$. Polysilicate chains are predominant in the constitution of crystalline samples heated $24 \mathrm{~h}$ at $710^{\circ} \mathrm{C}$; its XRD diagram is identical with that of the mineral alamosite.

\section{References}

[1] H.P. Calhoun and C.R. Masson, in: Review on Si, Ge, Sn and Pb compounds, ed. M. Gielen, Vol. V, No. 4 (Freund Publishing House, Tel-Aviv, Israel, 1981) p. 153.

[2] L.S.D. Glasser and E.E. Lachowski, J. Chem. Soc., Chem. Commun. (1980) 973.

[3] E.E. Lachowski, Cement Concrete Res. 9 (1979) 111.

[4] D. Hoebbel, G. Garzo, G. Engelhardt, R. Ebert, E. Lippmaa and M. Alla, Z. Anorg. Allg. Chem. 465 (1980) 15.

[5] D. Hoebbel, G. Garzo, K. Ujszaszi, G. Engelhardt, B. Fahlke and A. Vargha, Z. Anorg. Allorg. Allg. Chem. 484 (1982) 7.

[6] F.D. Tamás, A.K. Sarkar and D.M. Roy, Hung, J. Ind. Chem. (Veszprém) 5 (1977) 115; F.D. Tamás, A.K. Sarkar and D.M. Roy, in: Hydraulic Cement Pastes: Their Structure and Properties (Cement and Concrete Association, London, 1976) p. 55.

[7] H.P. Calhoun, C.R. Masson and M. Jansen, J. Chem. Soc. Chem. Commun. (1980) 575.

[8] J. Götz and C.R. Masson, J. Chem. Soc. A (1970) 2683; (1971) 686.

[9] J. Götz, D. Hoebbel and W. Wieker, J. Non-Crystalline Solids 22 (1976) 391.

[10] H.P. Calhoun and C.R. Masson, J. Chem. Soc. (Dalton) (1980) 1282.

[11] G. Garzó, A. Vargha, T. Szekely and D. Hoebbel, J. Chem. Soc. (Dalton) (1980) 2068.

[12] E. Thilo, W. Wieker and H. Stade, Z. Anorg. Allg. Chem. 340 (1965) 261.

[13] J. Götz, D. Hoebbel and W. Wieker, Z. Anorg. Allg. Chem. 416 (1975) 163.

[14] L.S. Dent Glasser, R.A. Howie and R.M. Smart, Acta Cryst. B37 (1981) 303.

[15] H.W. Billhardt, Glastechn. Ber. 42 (1969) 498.

[16] R.M. Smart and F.P. Glasser, J. Amer. Ceram. Soc. 57 (1974) 378.

[17] R.M. Smart and F.P. Glasser, Phys. Chem. Glasses 19 (1978) 95. 